DOI: $10.1515 /$ pof-2015-0018

VOLUME 7, ISSUE 3, 2015

ISSN: 2036-5438

\title{
Promoting solidarity in crisis times: Building on the EU Budget and the EU Funds
}

by

Katerina Pantazatou*

Perspectives on Federalism, Vol. 7, issue 3, 2015 


\begin{abstract}
This article examines the evolution of the EU 'redistributive' policies in the (post-) crisis EU era. By reviewing the EU cohesion policy, the financial assistance mechanisms, the new economic governance measures and the potentials of attributing the EU fiscal capacity, it aims to conceptualize the notion of solidarity as redistribution as this has evolved by reason of the crisis. The article argues that by virtue of the diverging economies, interests and preferences of the Member States, reciprocal or 'effects-based solidarity' is the only type of solidarity that has been exhibited among the Member States during the crisis. It, further, shows how the principle of solidarity has not lived up to its potential in the present crisis context, but it has instead been cropped up in sharply different ways in the rhetorics and communications of political parties of all hues across the Union.
\end{abstract}

Key-words

EU budget EU cohesion policy, EU Funds, crisis, redistribution, solidarity 


\section{Introduction}

There has been a lot of debate recently as to whether the EU has exhibited a spirit of solidarity during the crisis. The answer, I believe, depends on two variables; first, on how one defines solidarity, and secondly, whether there was/is room from a realistic and legal perspective to be solidary on a transnational level.

This article sets out up by providing an overview of the concept of solidarity and its evolution. It argues that by reason of the crisis the economic and social differences among the Member States have been exacerbated. This has further deepened the division between national or social and transnational or inter-state solidarity and has impacted on the decisions and choices of the Member States with regard to the national and the EU budget(s). In times when national budgets are shrinking it is more likely that the remaining funds will be used for national purposes, instead of transnational aid. This contribution will argue that by virtue of the increasing division, 'transnational solidarity' is to be discerned as a reciprocal or 'negative' concept. To bring that point home, I will explore the areas that pertain to the 'redistributive' character of solidarity; the EU cohesion policy, the financial assistance mechanisms, the new EU economic governance measures and the potential that the EU acquires fiscal capacity.

The article, hence, proceeds by delimiting the notion of solidarity for its purposes, into solidarity as redistribution. Upon reviewing the main redistributive policy in the EU, the EU Cohesion policy as it materializes through the EU Funds, I will turn to examine the new economic governance measures of the $\mathrm{EU}$ in order to investigate whether the 'EU redistributive' framework has been solidary and what type of solidarity it has been premised upon.

\section{The concepts of solidarity}

The concept of solidarity has been enshrined in the Treaties and has regularly been used under different Titles as a fundamental guiding principle, in particular when crises occur. ${ }^{I}$ In this 'crisis' context, the legislator has perceived solidarity as a 'positive' or altruistic concept which does not merely exist by reason of factual interdependence among 
the involved States. ${ }^{\text {II }}$ In its empirical, factual or 'commonly understood sense' solidarity expresses the support by one person or group of people for another because they share feelings, opinions or aims. It is, thus, perceived as an expression of altruism from groups of people towards others.

In lack of a definition of the concept in the Treaties and in view of its stable presence therein, the concept of solidarity encompasses different constituents and perspectives. In EU law, the most commonly employed division relates to the solidarity between Member States (inter-state or transnational solidarity) and solidarity between Member States and their individuals (social or national or intra-state solidarity). Both these types of solidarity can further be divided as altruistic or positive and reciprocal or negative.

Because of its abstract nature, the concept of solidarity is rather malleable from a legal perspective. Its legal 'provenance' and value although advocated, ${ }^{\text {III }}$ is debated, in particular by political scientists, and so is its enforceability. ${ }^{\text {IV }}$ Its lack of direct effect may often lead to the confinement of the concept in mere rhetoric, or might require its realization through more 'legal' and enforceable tools, such as the more precise Treaty provision pertaining to the EU's social policy, or the Charter of Fundamental Rights provisions.

Political and social scientists, philosophers and constitutional lawyers have repeatedly attempted to divide solidarity in specific models, either in terms of the different ideological and political contexts within which the concept was developed (for instance, the idea of Marxist solidarity, of the Christian democratic solidarity or of the classic social theory) or in connection to the societal preferences, functioning and development (Durkheim 1964). Other designations of the notion of solidarity have related to its constitutional 'standing' and evolution, or have distinguished solidarity pursuant to its many functions and expressions, such as the social and the redistributive ones.

Solidarity, in the sense of 'social' or 'intra-state' solidarity is further a relative, dependent, evolving and 'clashing' concept with implications at the supranational level. Its relativity draws a lot from the different understandings of solidarity at the national level, which, in turn, are shaped by long-established traditions and 'prosperity' or 'depression cycles'. Low levels of social welfare provided in many EU countries, both in more recent and more 'senior' members, possibly create different levels of expectations in comparison to traditionally high level protective Member States, such as the Scandinavian countries. Similarly to being a relative concept, solidarity is also a dependent concept. It often 
depends on a 'quid pro quo' interaction which can be discerned both at the national and supranational level. The trade-offs required for the redistributive state to perform, entail, in most cases, the choice among different levels and quality of supply of public (or quasi public) goods, different taxation systems and rates and different state intervention levels. These decisions usually take place at the national level and they are shaped in accordance with each state's traditions, culture and preferences, represented at a higher level by the elected governments. This way these choices enjoy democratic legitimacy. Naturally, these national preferences and benchmarks are then, transposed to the EU level, creating different expectations and different dispositions towards the associated 'trade-offs' among people who are united by a certain degree of economic integration, but not by any sense of demos or identity.

It is, in principle, the EU who has to bridge these different dispositions via harmonization or regulation. The situation is similar at the EU level, where choices have to be made both with regard to the objectives of the redistribution, the share each of the partners contributes, the anticipated results and the potential gains for all the participants. At this redistribution level the EU is, thus, called to perform some sort of cost benefit analysis while respecting and allocating -to the extent possible - the different political, economic and social backgrounds of the Member States.

The witnessing of the deterioration of social benefits and services-in particular in the financially assisted Member States, and the increase of the economic, social and political disparities among the Member States by reason of the crisis made more skeptical the people of the Union with regard to the EU's room and willingness to act against the crisis. The 'bail out' mechanisms that prevented the default of some countries and the state aids that halted the bankruptcy of major banks could be perceived more as an effort to save the Eurozone and the huge economic interests involved, rather than as an attempt to alleviate the burden from the socially disadvantaged. Similarly, the dire economic situation and the shrinking budgets of most Member States were calling for swift decisions with regard to solidarity; solidarity within the state and towards each state's own nationals, or transnational solidarity that would help keep the EU construct together? The perception of the peoples of Europe would play a key role in this dilemma, as the democratically elected governments would, at least in theory, be called to apply policy choices for and from the people (input and output legitimacy). However, despite the intergovernmental character of 
the new economic governance measures, democratically deliberative decision-making remained absent in the process of their adoption. With or without democratic legitimation, in view of this economic situation, the increasing divide between the Member States and the growing uncertainty about the future, the solidarity to be 'provided' would, inevitably, be limited and could not any more function in its altruistic understanding but had to come with guarantees, safeguards and mutual returns for all participants (Giubboni 2010). ${ }^{\mathrm{V}}$

\section{Solidarity as redistribution: Altruism versus Reciprocity}

In most scholarly literature solidarity is deeply connected to redistribution and, in turn, to distributive justice. Should there be redistribution, what purposes should it serve and should it be connected to moral assessments are only a few questions that pertain to the concept of solidarity. ${ }^{\mathrm{VI}}$

In EU law solidarity has been perceived as a legal concept. Already in the TEC the Communities intended to promote inter alia economic and social cohesion and solidarity among Member States (Article 2 TEC). The instutionalization of solidarity which has underpinned the EU integration project since its very beginnings has historically served to bridge 'social conflicts and redistributing resources in accordance with the normative assumptions that are implicit in a polity' (de Witte 2012: 704). Solidarity has, thus, been associated (both at national and supranational level) not only with the concept of redistribution which constitutes the means to achieve it, but also with the concept of social justice (the purpose or the normative assumption), including the promotion of social rights, labour and employment rights, fundamental rights and related policy areas that derive from a welfare state. But in the 'quid pro quo' trade-off between market principles and social objectives, the Court of Justice has repeatedly given priority to economic integration and market(s)' liberalization while ignoring the 'social state'. ${ }^{\text {II }}$ This finding cannot be disassociated from the fact that it has been the economic freedoms and the competition law provisions in the Treaties that constituted the motor of the European integration throughout the years. While the Member States agreed to a transfer of powers with respect to the aforementioned economic policy areas to the EU, powers relating to the social sphere and the welfare state remained at nation-state level, where it was believed they could be better addressed. As social policies remained decoupled from the 'economic' European 
project, economic integration was advancing while social integration was lagging, to say the least, behind. Thus, the welfare state evolved along territorial lines based on - however diffuse - notions of national solidarity between citizens of nation States. By being 'stranded' at the national level, the welfare or social state was dependent on redistributive choices at the national level.

This article will examine redistribution as a constituent of solidarity. ${ }^{\mathrm{VII}}$ Redistribution, in turn, is to be understood as distributive justice or distributional equity. ${ }^{\mathrm{IX}}$ Redistribution as a constituent of solidarity and as an essential component of most welfare states has been shaped through time by social, political and economic considerations and within the appropriate historical contexts. Similarly to the concept of solidarity, redistribution is characterized by a relative, evolving and contextual nature. Rawls's preference for a consumption tax to an income tax, and a flat tax rate over a progressive tax rate, for instance, sits uneasily with the empirical understanding of '(re)distributive justice' or the best means to achieve it. ${ }^{\mathrm{x}}$ Similarly, a progressive income tax rate of up to $70 \%$ (with a redistributive purpose) for the very wealthy taxpayers would possibly be perceived as 'fair' by the beneficiaries of redistribution but unjust for the highly taxed people. These choices are usually reflected at Member State level through elections, and as they entail income and/or wealth reallocations they require enhanced democratic legitimacy. Compulsory taxation and the associated tax transfers, for instance, as the main source of redistribution are telling of the need for increased democratic legitimization and as such they still remain within the nation-state (or Member State ambit). ${ }^{\mathrm{XI}}$

In the current crisis framework the first question that arises is whether the redistribution that takes place at the supranational level serves welfare purposes (distributive justice). Secondly, should the materialization of 'transnational solidarity' via 'state redistributions' be decoupled from motives and moral assessments behind redistribution? In other words, should solidarity as redistribution at the state contribution level be connected to the ideas of altruism, empathy and of noble moral motives?

As with the case of 'justice as reciprocity' advanced by John Rawls, Brian Barry and many others, solidarity (as redistribution or in any other form) can materialize even under pure reciprocal or quid pro quo grounds, whereby the contributor shares with the recipient in anticipation of a (future) counter-contribution or fair return. ${ }^{\mathrm{XII}}$ For some authors, however, motives do matter when defining solidarity. Accordingly, the behavior as such is not 
sufficient to establish solidarity if it is not accompanied by an appropriate kind of belief and altruism (Harvey 2007). A more moderate approach with regard to the values of altruism and self-interest in solidarity has been expressed by Viehoff and Nicolaidis, who placed solidarity in their 'solidarity compass' at the intersection of the two continuums of self-interest and Community and of altruism and obligation. For them, solidarity describes 'a relationship that is motivated to some extent by each of these powerful motives, but [remains] irreducible to either one of them' (Viehoff and Nicolaidis 2015).

Understanding solidarity as redistribution and accepting the idea that this concept need not necessarily encompass any altruistic or empathetic elements is crucial in order to evaluate whether the EU response in the current crisis has exhibited a spirit of solidarity, as termed for the purposes of this contribution. If one, however, disassociates solidarity from any motives and moral assessments, solidarity will be assessed only by reason of its effects to distributive justice and the welfare state.

As the following parts aim to highlight, in the EU redistribution context there is no pure altruism. In the best case scenario one can place solidarity in the 'solidarity compass' at the intersection of the aforementioned continuums. This, however, does not mean that solidarity is absent altogether in the (post-) crisis legal framework. By contrast, as the EU cohesion policy and the new economic governance measures' analyses will show, it exists partly by virtue of its effects and processes rather than by reason of the intentions behind it.

At present, redistribution is divided in the EU. Similar to direct taxation, redistribution is entrusted, to a large part, to the Member States - in agreement with the fiscal federalism theory. It is the Member States, in principle, that decide how they will allocate their revenues, how they will form their budget and to what degree they will opt for a 'social' and welfare state model. In accord with that, the main instrument for redistribution, taxation, is almost entirely reserved for the Member States. In an effort, however, to balance the uneven distributive impact of Europeanisation the EU has obtained an institutionalized and constitutionalized redistributive role which is fulfilled by virtue of the EU budget and the EU cohesion policy (EU funds) and through regulation both at EU and national level.

\subsection{The EU Cohesion Policy}

The EU Cohesion policy is dedicated to bridging the discrepancies among the various Member States and to assisting the Member States 'in need'. It thus, aims to attain 
economic, social and territorial cohesion among the Member States (Art. 174-178 TFEU) and it currently figures as a major cornerstone in the 'Europe 2020' strategy. After the numerous and complex reforms it has undergone, since its first appearance in the mid1970s, the EU Cohesion policy, which is effectuated through the EU Funds, currently accounts for a large part of the EU budget at EUR 351.8 billion for the period 2014-2020. Consequently, a large part of the EU budget is being spent on effectuating the EU cohesion policy into the major redistribution policy instrument in the EU.

The EU cohesion policy has an important place in EU philosophy and is governed by the 'redistributive idea' which stems from the intuitively reasonable assumption that the 'less favoured' regions are in need of 'EU funding' in order to be able to compete in the common market against the more favoured ones. ${ }^{\text {XII }}$ This idea of the 'subsidization' by the beneficiaries of European integration and regulatory competition seems to match partly, Maduro's idea of being solidary 'by establishing a link between the wealth generated by European integration and the requirement to distribute it fairly' and seems to confirm the idea that solidarity in EU law should be discerned as a 'reciprocal' concept (Maduro 2012: 6). As a redistributive idea, the EU cohesion policy is intrinsically linked to the development of the EU budget.

The, by comparison, small amounts destined to reduce the regional economic and social disparities among the Member States and their regions are per se a problem in the realization of this goal. The unwillingness of many Member States to contribute to this redistributive policy is the second obstacle in this process. As the role of cohesion policy is to bring closer the richer and poorer parts of the EU, it is inevitable that the EU budget allocations would not be unanimously endorsed. National interests in the amounts and the allocations involved are divided, with the 'traditional net payers' or, in other words, the 'richer' Member States opposing more spending and the traditional 'beneficiaries' or the poorer States aiming for even more financing to compete with the richer ones on equal grounds (Bachtler et al. 2013). ${ }^{\mathrm{XIV}}$ This opposition to a larger EU budget for redistributive purposes has been exacerbated as a result of the crisis. The 'profligate south', a habitual recipient of EU Funds, being in a dire economic situation, inevitably asks for more money, whereas the 'prudent north', the main financier of both the EU funds and the EU financial assistance has been more hesitant to disburse funds merely for benevolent reasons established on mutual trust and the need for a more coherent Europe. 
On the same reciprocal basis, the political bargaining, inherent in the decision-making procedure that leads to the adoption of the EU budget has been extended also in the 'greatest redistributive' representative policies of all, the EU cohesion policy. Many Member States have used cohesion policies as a bargaining tool to obtain resources in return for political compromises (Nicola 2015) or as a side-payment and a redistributive mechanism for budgetary contributions to compensate states in the context of a new enlargement (Wishlade 1996) or even as an enforcement mechanism in case a Member State does not respect the rule of law desiderata (Closa et al. 2014). In the last case, the Commission has repeatedly suspended the EU funds' disbursement to Hungary on grounds of unscrupulous processes in the selection of projects (2015) of the transfer of responsibilities of the funds' administration to the Office of the Prime Minister and other ministries (2013) and of excessive deficits (2012).

The source of this lack of altruism in a purely redistributive policy could be found in the diametrically different economies, and by implication, to the diverging preferences and priorities of the Member States, the lack of a 'Union' and a common ethos, demos and purpose. It can also be justified by the different 'performance' of the Member States in the implementation of the EU cohesion policy which pertains to their different administrative, absorption and spending capacities, their participation and administrative cultures, their corruption levels as well as the complicated and multi-level governance the EU has designed for this policy.

The first pitfall relates to the poorer Member States' capacity to absorb and utilize the allocated funds. The complex legal framework of the ESI Funds necessitates a very sophisticated administrative capacity at Member State level to manage and implement the Funds. In consequence, the spending capacity of the Member States depends largely on the ability of the (multiple) involved authorities, at national, regional and local level to set up authorities adept at complying with the highly demanding administrative work entailed, as well as to the ability of the Member States or regions to secure co-financing for the projects (Regulation 1303/2013, Recitals 26 and 105). Such an undertaking comprises the selection of the projects to be financed, in accordance with the multi-annual planning approved by the Commission and the monitoring of their implementation. Evidence from the Commission, for the programming period 2007-2013, highlight a series of other factors that affect the low absorption rates by some Member States, including the challenges in 
preparing major infrastructure projects and obtaining the Commission's approval, the changes in EU legislation and the changes in the national political set up (including changes in national and regional governments).

Similarly to the administrative incapacity of some Member States to absorb the funds, the principles of additionality and complementarity that undergo the EU Funds aim at ensuring that the funds provided by the $\mathrm{EU}$ are not intended to substitute national investment but only to supplement it. In conjunction with the co-financing principle, thus, the EU can only partly finance projects. Although this requirement might pose significant problems to the absorption of the funds by the poorer Member States, the Commission has, by reason of the crisis, waived or reduced the fixed co-financing rates in order to facilitate the disbursement of EU funds. Furthermore, taking stock of the prior problematic implementation of the EU cohesion policy instruments by the Member States, Regulation 1303/2013 has placed particular emphasis on thematic and general ex ante conditionality provisions. Compliance with those conditionalities, however, although aiming at ensuring a better implementation of the EU funds, it also increases the administrative and real costs for the candidate Member States. ${ }^{\mathrm{XV}}$

Besides the different absorption levels of the Member States, the implementation of the EU Funds relates further to the diverging political, administrative and cultural 'profiles' of the Member States. The partnership principle is another distinctive principle of the EU cohesion policy and is complementary to the shared management principle. Its main goal is to involve, throughout all the stages (implementation, monitoring and evaluation of Partnership Agreements), different actors at both supranational and national level in order to

'ensure respect for the principles of multi-level governance, and also of subsidiarity and proportionality and the specificities of the Member States' different institutional and legal frameworks as well as to ensure the ownership of planned interventions by stakeholders and build on the experience and the know-how of relevant actors.' (Regulation 1303/2013, Recital 11).

The involvement of different actors (national, sub-national, private, NGOs) in the decision making and implementation process depends on the different political 'traditions' 
of the Member States and certainly affects the outcomes of the EU Cohesion policy. The 'north' versus 'south' divide is conspicuous also in this respect; Southern countries tend to 'centralize' the decision making, whereas the northern countries are more apt to the involvement of other actors in the decision making process. This, certainly, has an impact on all levels of the implementation process, from the priorities and the goals to be served, to the project-selection process. Likewise, the different corruption levels at various Member States influence the EU funds' allocations. While examples of mismanagement, fraud and EU money waste are not to be found only in 'southern' countries, it is mostly the countries with the highest corruption perception index (CPI) that either fail to carry out the projects they were funded for, or prove to have invested the money in poor 'value for money' projects.

The European Anti-Fraud Office (OLAF) and the European Court of Auditors (ECA) provide ample data that bespeak the EU Funds' amenability to abuse and fraud. During the annual audit the ECA carried out for 2013, it found with regard to the regularity of the transactions underlying the EU accounts, that while both revenue and financial commitments for 2013 were regular, the estimated error rate for 2013 payments was 4.7\%, remaining persistently higher than the "materiality threshold" of 2\%. (ECA 2014a) Errors arise when payments from the EU budget 'are neither legal nor regular, for example when claimed by ineligible beneficiaries, for expenditure that should not be financed by the EU, or when the conditions for receiving the aid are not followed.' (ECA 2014c) Thus, for a payment to be classified as 'error' it has to be contrary to the law and have a potentially harmful impact on the EU's financial interests.

Typical sources of error, besides compliance with eligibility criteria, include serious breaches of public procurement rules either deliberately, in order to favour certain applicants over others, or inadvertently because of the complexity of the rules (ECA 2015); effectively 'poor' checks and controls by both the Commission and the Member States, focus of the Member States on the absorption of the Funds rather than on their 'good spending' and incorrect declarations of agricultural areas. (ECA 2014a)

With regard to financial recommendations, upon conducting significant investigations, OLAF recommended in the area of EU Funds a financial recovery of 476.5 million Euros for year 2014, almost triple the size in comparison to the next in the ladder external aid (amounts recommended by OLAF for financial recovery in this sector, 174.0 million 
Euros) (OLAF 2014). Similarly for 2011, OLAF revealed that of the total amounts recovered, approximately $85 \%$ comes directly from the EU Funds. ${ }^{\text {XVI }}$

One cannot, therefore, be taken by surprise at the suspiciousness of the 'performing' and 'donor' Member States regarding the value and effectiveness of the EU Cohesion policy as well as the geographical coverage of the policy. ${ }^{\text {XVII }}$ The incapacity of some states to absorb the funds, or to spend them in the best possible way often results in unfinished or poor value for money results which in turn, deepens the divide between intra- and interstate solidarity. Why 'waste' money on a 'lost cause' when this money could be used for improving the wellbeing of your own 'nationals'? The discontent of some Member States about the continuation of the 'cross-subsidization' of the poorer regions and states shows, once again, that solidarity in the EU should not be understood in its altruistic capacity. This is further advocated by the fact that this subsidization does not come for free and is not unlimited. Member States have to participate in the financing of the projects in accordance with the additionality and complementarity principles and they have to provide evidence as to their capacity to absorb and manage these funds towards the desired goal.

The Member States, their different cultures and their very different economies and interests are not the sole culprits of this building of apprehension, and possibly even, mistrust behind this redistributive policy. The role of the EU in this is not to be neglected; the number of material errors, and everything this is associated to, could certainly be reduced had the disbursement of the EU Funds been properly and adequately monitored and sanctioned by the EU when needed. The current legal framework leaves too much leeway to the Member States not only to implement the ESI Funds but also to monitor this implementation. ${ }^{\mathrm{XVIII}}$ Among the ex post conditionalities, lays the Commission's or the Member States' obligation in close cooperation with the Commission, to carry out evaluations in order to examine the effectiveness and efficiency of the ESI Funds and their contribution to the Union strategy for growth. In case of non-compliance with the designated criteria (as these are laid out in the Partnership Agreements) the most severe remedial action is the suspension of the interim payments or a reduction of the funds to be disbursed, a remedy that does not seem sufficient to deter mismanagement actions. Similarly, in case the preemptive ex ante conditionalities fail to ensure compliance with the 
EU standards, the Member States and/or the Commission can impose financial corrections, in other words, they may recover payments that should not have been paid out.

The often 'poor results' or the questionable motives, however, do not negate the positive effects of the EU cohesion policy to the 'welfare state'. Indicatively, only for part of the programming period 2007 - 2013 and only by virtue of the ERDF co-financed interventions, approximately 593,954 jobs had been directly created across the EU. (European Commission 2014c).

\subsection{The EU Budget as an expression of solidarity}

The EU budget and the EU funds disbursed therefrom do not constitute the only means of redistribution in the EU. Redistribution can be achieved through regulation in other EU policy areas, for instance via the Single Resolution Mechanism and the Single Resolution Fund or via 'distributional steering' at the national level through the involvement of the EU in the budgetary policies of the Member States. ${ }^{\mathrm{XIX}}$

In a complete economic Union where the EU would be granted tax raising powers, redistribution could further be attained through taxation and in the post-crisis framework redistribution can be attained through the financial assistance mechanisms such as the ESM and the EFSF.

\subsubsection{The first hybrid indirect redistributions in the face of the crisis}

The EU budget constitutes the main form of redistribution in the EU. In lack of an EU fiscal capacity, whereby redistribution would depend largely on the revenues arising from taxation, redistribution via the EU budget is currently effectuated through regulation, as the example of the EU Cohesion policy demonstrates. The crisis, however, and the need for imminent actions in order to save countries from defaulting and the Euro-currency as a whole initiated new structures, what I term for the purposes of this article, hybrid indirect redistributions.

The first type of 'hybrid indirect redistributions' materialized through the granting of financial assistance to the Member States in need, either through the European Stability Mechanism (ESM), and earlier under Memoranda of Understanding (MoU) or the European Financial Stability Mechanism (EFSM) or the European Financial Stability 
Facility (EFSF). These indirect redistributions were not effectuated directly via the EU budget, but instead they constituted some form of fiscal transfers among the Member States. These transfers have temporarily - at least - contributed to the rescue of certain Member States in need and have, thus, exhibited a spirit of assistance in that each euro area Member State has participated with its capital to the ESM.

But are these two elements sufficient to mitigate the 'negative' solidarity caveats the financial assistance mechanisms entail; First of all the conditionalities attached to all the financial assistance programmes and secondly the ulterior motives behind their granting. It has been argued that the institutionalization of these financial assistance mechanisms, which was culminated with the establishment of the permanent ESM, marked the transition from 'negative' to 'positive' solidarity and demarcated a new era for 'normative' solidarity (Borger 2013). This 'crisis-induced' shift can be illustrated, according to Borger, via the 'departure from an economic policy that is predominantly focused on budgetary prudence and price stability to one that takes better into account financial stability as well.' The broad interpretation of the 'no-bail out' clause by the CJEU in the Pringle case, ${ }^{\mathrm{xx}}$ and the authorization the CJEU gave the ECB for bond-buying in the secondary markets ${ }^{\mathrm{XxI}}$ point indeed towards a more 'altruistic' version of solidarity, one that aspires to the common good.

While, indeed, both from an ex post factual assessment, as well as from a strictly legal perspective, the financial assistance that allowed some Member States not to default cannot be overlooked, ${ }^{\text {XII }}$ the motives and the conditions attached to this financial assistance are not, in my view, capable of altering the reciprocal character of solidarity into an altruistic or positive one (Hilpold 2014). With regard to the ulterior motives behind the granting of financial assistance, as the press at that time argued, the granting of assistance aspired to the saving of the Eurozone as a whole, given the possible domino effects the default of one Eurozone country could cause to the other Eurozone members. This finding is further reinforced by the fact that the response to the two alleged causes of the crisis, the EU's structural problem of a single currency union without a fiscal union, in other words the EU being a non-optimal currency area, and the fiscal profligacy of the Member States resulting from the unenforceability of the Stability and Growth Pact, was initially focused on enhancing fiscal surveillance and fiscal discipline in the EU. 
Despite many political assertions that one of the driving powers behind the strengthening of stability, unity, and integrity of the euro area was solidarity, Draghi's speech in July 2012 who reassured the markets that "the ECB is ready to do whatever it takes to preserve the euro. And believe me, it will be enough" revealed the true motives behind the 'solidary character' the EU and the Member States had demonstrated recently. Certainly, one could not expect much more from an independent institution entrusted with conducting the monetary policy of the Union (Article 282 TFEU).

However, it soon became clear that the use of the 'solidarity rhetorics' in various political statements, both at national and supranational level, was not sufficient to upgrade the solidarity principle into a critical principle in the crisis resolution nor to attribute it a 'positive' or altruistic meaning. As such, despite solidarity being a legal concept in EU law and a long-standing principle in the process of the European integration, it has not unfolded to lead to in concreto solutions in the present crisis. From the recent economic governance measures, the concept of solidarity, surprisingly, figures only in the Preamble of the ESM Treaty, where it is confined in the statement that ' $[T]$ his Treaty and the TSCG are complementary in fostering fiscal responsibility and solidarity within the economic and monetary union.' Similarly, the concept of solidarity was entirely absent in the Pringle judgment with the exception of the citation of Art. 122 TFEU, which makes reference to the principle. The Court, unfortunately, did not build upon AG Kokott's opinion, who elaborated on the concept of solidarity and the requirement to provide inter-state financial assistance, and missed, hence, an opportunity to define transnational solidarity in its EMU and crisis contexts.

Similarly, the very strict conditionalities attached to the provision of financial assistance are, certainly, not sufficient to cancel out the financial assistance's redistributive character but could prove adequate to refute the financial assistance's 'positive solidary' character. They instead, simply, ascribe a different feature to the notion of solidarity, that of a reciprocal disposition, or rather a 'solidarity of fact'. The conditionalities the bailout programmes entail, for instance, fail to promote social solidarity as they impinge upon the social policies of the Member States and they often require introducing detrimental to the welfare state measures. ${ }^{\text {XXIII }}$ They, hence, aim at ensuring that the benefited States will comply with the 'budgetary discipline' attached to the assistance and that moral hazard will 
be avoided rather than guaranteeing that the citizens of the assisted states will enjoy a higher degree of welfare at no additional cost.

\subsubsection{The 'supranational regulation' of national budgetary policies: a new window of opportunity?}

The second hybrid form of redistribution relates to the EU's increased participation in the formation of national budgets. This enhanced role, in particular by the Commission, has been reinforced by the new crisis legal instruments, such as the European Semester and the Six-Pack. ${ }^{\text {XxIV }}$ The former aims at intensifying, synchronizing and centralizing the coordination of national budgets and economic policies by allowing the Commission to review the Member States' budgets and to assess whether the national draft budgetary plans comply with the 'Sic Pack' criteria. At the end of the calendar year, and the beginning of the 'Semester cycle' year the Commission publishes its Annual Growth Survey and its Alert Mechanism Report which identifies the Member States that need an in-depth review because of the potential imbalances detected, likely to disrupt the smooth functioning of the Member States' economies. Based on the findings of these reviews the embedded in the European Semester Macroeconomic Imbalances Procedure (MIP) might be triggered, and if the imbalances are considered excessive the Excessive Imbalance Procedure (EIP) will be launched. In contrast, if the imbalances are not found excessive the 'preventive arm' of the MIP will be activated and the Commission's recommended policy responses to the imbalances will be integrated into the Country Specific Recommendations (CSR).

Looking at the specific country recommendations for 2014, one can observe that some recommendations address sensitive issues relevant to Member States' national sovereignty, like taxation and social policies. The conditionalities attached to any (pre- or post- ESM) financial assistance, as well as the Country Specific Recommendations made by the Commission to the Member States have direct and immediate implications for the economic and social policy choices for the future of Europe and its Member States, pertaining for instance to employment, social security and taxation issues. These recommendations, whether of a very specific nature or not, can produce sanctions under the Excessive Deficit Procedure and the Excessive Imbalance Procedure, if the Member States fail repeatedly to take action on public finances or macroeconomic imbalances respectively. This possibility of intervention to the national budget-planning of the Member States given to the European Commission under the European Semester in conjunction 
with the Six-Pack can open new pathways for the EU to promote both transnational and social solidarity. As the improvement of employment policy and social protection figures among the cornerstones to boost growth, I see this involvement as a window of opportunity for the Commission to coordinate all budgets towards a welfare state. While this statement is quite far-fetched, in particular as the potential sanctions for nonperformance relate not so much to the specific recommendations but rather to the achieved results with regard to the macroeconomic imbalances and public finances, it is useful to demonstrate the increased involvement of the Union in national budgetary decisions. ${ }^{\mathrm{xx}}$ This expanding intervention signifies, further, a disregard -on behalf of the Union -- of the 'higher democratic legitimacy' required in fiscal and budgetary policies, than the one delivered by a strongly intergovernmental approach. Leaving, however, aside the democratic legitimization of the Commission, and the Union altogether, to have a say in, if not dictate, the budgetary policies of the Member States; the bait lies for the EU, in balancing, when interfering to the national budgets either through the conditionalities or via the Semester means, market and social objectives. Fiscal entrenchment and consolidation and the promotion of social policies and employment are not always easy to match. Fears are increasing, therefore, as to whether the EU's goals include the promotion of a welfare state or whether they will advance '[...] a regime that would allow for the projection of market imperatives onto national budgets without any specific democratic legitimation' (Habermas 2011).

While the history of European integration, the crisis legal framework as well as the case law of the CJEU point towards a market-oriented approach, the dire economic and, often, humanitarian situation of many Member States has pushed the EU decision-makers to review the impact of the new economic governance measures on the social policies. According to the "five presidents" report 'employment and social concerns must feature highly in the European Semester. Unemployment, especially long term unemployment, is one of the main reasons for inequality and social exclusion.' In order to promote more 'social cohesion' and 'social justice' the European Commission can commence from promoting through its interference in the national budgets more 'socially' or 'solidary' (in its social sense) policies. Such a venture could be achieved, for instance, by taking social imbalances into account when assessing convergence and imbalances (Notre Europe Policy Paper), or by 'coercing' the Member States to apply social redistributive measures, such as 
progressive taxation, or wealth taxes or special levies on luxury goods, instead of increasing taxes related to labour. Through this 'backdoor' intrusion, the EU as a whole can for the first time influence the 'hard core' national policies towards a more 'social justice' oriented goal.

\subsubsection{The 'potential': Attributing the EU a fiscal capacity?}

By reason of the fact that the EU is not a federal state, it is caught in the paradoxical situation where it has little fiscal capacity but regulates the fiscal conduct of the member states (Hallerberg 2014).

The recent discussions on the possibility of attributing the EU fiscal capacity, in other words, giving the EU the power to raise taxes, in order to create a 'federal budget' that could be used as a 'crisis-buffer' are stretching the EU's competences and challenge its creativity in finding new ways to overcome constitutional and institutional problems. ${ }^{\mathrm{X} v \mathrm{X}}$

The primary advantage of granting the EU fiscal capacity would be the increase of the EU budget. The second big advantage is that the transfer of tax raising powers to the EU, provided it is democratically legitimized, would 'democratize' also the EU's spending powers.

The Van Rompuy report recommended that the central level of the euro area should be equipped with powers for common decision-making on national budgets or else be given a fiscal capacity of its own. ${ }^{\text {xxII }}$ By analogy with the existing minimal EU budget, a fiscal capacity could be funded from contributions of member states in relation to their economic output, or via a fixed share of national taxes (e.g. value-added tax), or a common European tax like the financial transaction tax (FTT), which, however, unlike the FTT would have to be collected in all Member States. Such an option would require Treaty amendments, providing, inter alia, the legal basis for 'a new taxation power at the EU level, or a power to raise revenue by indebting itself on the markets (presently barred by Articles 310 and 311 TFEU)' (European Commission 2012). Such a central fiscal capacity could materialize, according to the van Rompuy report, via the establishment of a mechanism 'where contributions and disbursements would be based on fluctuations in cyclical revenue and expenditure items, or on measures of economic activity' (macroeconomic approach) which would 'be more directly linked to a specific public function sensitive to the economic cycle.' 
The Commission's discussion on the fiscal capacity of the EMU, suggesting, among other solutions, a Treaty amendment to include a legal basis attributing tax raising powers to the EU seems highly unlikely in view of the unanimity required under the ordinary legislative procedure in order to proceed to such a conferral of a new competence. ${ }^{\text {XxIII }}$ The merits of such an unrealistic proposal were listed by the Commission in the same document: 'In contrast, that problem [the fundamental accountability problem in case of joint and several guarantees of all euro area Member States] would no longer arise in a full fiscal and economic union which would itself dispose of a substantial central budget, the resources for which would be derived, in due part, from a targeted, autonomous power of taxation and from the possibility to issue the EU's own sovereign debt, concomitant with a large-scale pooling of sovereignty over the conduct of economic policy at EU level. The European Parliament would then have reinforced powers to co-legislate on such autonomous taxation and provide the necessary democratic scrutiny for all decisions taken by the EU's executive. Member States would not be jointly and severally liable for each other's sovereign debt but at most for that of the EU' (European Commission 2012).

Regardless of the political unlikelihood of attributing taxing powers to the EU, the latter should not be confused with 'tax harmonisation'. Article 311 (2) TFEU on the Union's own resources provides that the Council may establish new categories of own resources, upon unanimous approval by the Member States. The use of this provision as a legal basis for the establishment of an EU tax has been contested. An expansive reading of Article 311 (2) TFEU would argue that under the 'Own resources' provision, the Council (acting unanimously) could actually also introduce outright, as a new 'own resources' even an EU income tax (Plasschaert 2004). In contrast, a more restrictive reading, interprets the provision as only implying that the Member States cannot refuse to pay their contributions to the EU budget.

While the relationship between the 'approximation of tax laws' provisions (Art. 113 115 TFEU) and the 'own resources' one (Art. 311 TFEU), is unclear, the political constraint of unanimity they both suffer from makes the chances of harmonisation of tax laws or the creation of a new tax, rather limited. The adoption of the indirect Financial Transaction Tax (FTT) under Article 113 TFEU and not under Art. 311 (2) TFEU, is a curious one. One reason for the selection of this legal basis could be the fact that 
'part of receipts generated by the FT'T shall constitute an own resource for the EU budget $[. .$.$] and the portion of the FTT revenue that remains in the national budgets could$ be used to help consolidate public finances, invest in growth-promoting activity or meet development aid commitments. Ultimately, it will be for participating Member States to decide how the revenues of the FT'T should be used.' ${ }^{\text {XxIx }}$

Another possibility lies in the preexistence of this type of tax in the most national orders' of the Member States, which would call for 'harmonization' of the existing taxes. A more suspicious 'reading' of this choice could possibly argue that the choice of Art. 113 TFEU allows for enhanced cooperation to apply (if there is no unanimity), as happened in the FTT case, while art 311 TFEU cannot be circumvented by enhanced cooperation (meaning that decisions can only be taken unanimously). Indeed the possible application of enhanced cooperation in the establishment of an 'EU tax' under Art. 311 TFEU would create practical problems, in the sense that a number of Member States would be forced to pay their contributions -in the form of the newly established taxes, while another one would contribute to the EU budget via the traditional own resources means. ${ }^{\mathrm{xxx}}$ Such a possibility, however, by creating an additional taxing burden (raised revenue for public services) to the taxpayers of the participant states, will lead to inequalities within the EU and most likely to a 'two-tier' EU budget; An 'enhanced' one and the 'traditional' one.

Even if we assume that Art. 113 and/or Art. 311 TFEU are meant to give the Eurozone tax raising powers, a statement the Commission does not endorse, we should not neglect the (unfeasible or not very probable to be attained) unanimity required under both provisions. This unlikelihood in conjunction with the unlikelihood, to say the least of a Treaty amendment, suggests one possibly (more) tenable solution; building the tax raising or tax policy making power of the EMU on the legitimacy-shaky grounds of the enhanced cooperation, as was eventually employed for the introduction of the Financial Transaction Tax. This circular argument presupposes the (problematic) choice of Art. 113 TFEU as a legal basis. Recourse to the passerelle clause, if accepted at the Council level, would enhance the democratic legitimacy of such a decision but would certainly add to the unfeasibility of such an undertaking. ${ }^{\text {xxxI }}$

All these political and legal constraints advocate the reliance of the EU on other institutional 'ways out' such as the creation of an EMU Treasury within the Commission and a corresponding, dedicated budgetary and own resources procedure, ${ }^{\text {XXXII }}$ which 
certainly comes with its own set of problems, most notably acceptance by the participating Member States and democratic legitimization. Other solutions proposed in the framework of a 'fiscal federation by exception' (Trichet 2012, Vanistendael 2010 and 2011) suggest the setting up of a ministry of Finance of the Euro area, which would have the responsibility of the activation of the economic and fiscal federation when and where necessary, while it would be responsible for the handling of the crisis management tools like the ESM. Another suggestion advances the ECB as the optimal solution, an institution which certainly does not meet the democratic legitimacy criterion, or a new institution to be created within the Euro group that would fulfil the political legitimacy and accountability criteria (Vanistendael 2010).

Regardless of the potentials of such tremendous institutional and constitutional changes, the fact that at a political level such ambitious projects of centralisation are being contemplated demonstrates the change in the perception and the mentality of the EU executives that are trying to find ways to build a 'fiscal Union' as a complement of the EU and as an antidote to the current and future crises. If this undertaking is implemented and on condition that it meets the necessary legality and legitimacy criteria, it will provide the first opportunity for the EU citizens

\section{Conclusion}

The answer to the question whether the EU, faced with the recent unprecedented crisis has demonstrated a solidary spirit, depends on one's understanding of the concept of solidarity. As the analysis of the EU 'redistribution framework' showed even in the 'most redistributive policy of all', the EU Cohesion policy, political conflicts and bargaining show that there is no room for purely altruistic motives and transfers completely detached from self-interest or Member States' interdependencies. For this it is not only the Member States to be denounced. Instead, this 'negative' or 'reciprocal' solidarity is inherent in the EU by reason of the huge differences among the Member States and the lack of a common demos and ethos among the EU people. The different interests, performances and preferences displayed by the participating Member States at the EU cohesion, the financial assistance and the new economic governance branches are telling of the unfavorable environment within which a positive or altruistic solidarity was expected to flourish. Despite the lack of 
these normative elements, the invention by the EU of new mechanisms to redistribute money and to better monitor the budgets of the Member States proves that inter-state solidarity in its reciprocal or 'effects-based' form was exhibited at an inter-state level.

While social justice and 'social solidarity' were not the main drive behind the financial assistance measures, a window of opportunity has opened to the EU to promote its social values through its increasing interference in the budgets of the Member States as stipulated in the Six Pack and the European Semester. Despite the democratic legitimization deficit this competences' expansion entails, this opportunity, if utilized accordingly by the Commission, could allow the EU to finally assume an active role towards a 'bottom-up' approach for an 'EU social policy'.

The lesson from the EU response to the crisis is not only that solidarity, at least in what concerns the EU 'redistributive' policies, cannot be understood as an altruistic or positive concept, but also, rather gloomily, that it seems completely deprived of its legal value. The fact that (transnational) solidarity is not considered among the main driving principles behind the recently adopted measures as a response to the crisis, but it has instead cropped up in sharply different ways in the rhetorics and communications of political parties of all hues across the Union is demonstrative of the malleability of the principle as well as the self-interest motives that underpin it. ${ }^{\text {xxxII }}$

Against the hybrid but effective redistributive mechanisms created by reason of the crisis, the road towards a fiscal Union that would allow the EU to raise taxes and operate a federal budget seems long and the prospects of an EU fiscal federation appear bleak. Such an undertaking would require, in addition to the revision of the current legal framework, an increased democratic legitimacy that could only be provided if the people of Europe were united by a common identity.

In lack of other effective redistributive means in the EU, the better management of the EU budget should be put in the spotlight. In this respect, in order for optimal redistribution to be achieved and social and economic cohesion to be attained, a revision and simplification of the current very complex multi-level governance structure of the EU Funds is needed and better monitoring and sanctioning on behalf of the EU is required.

\footnotetext{
*FNR - Marie Curie Post-Doctoral researcher, University of Luxembourg (aikaterini.pantazatou@,uni.lu). The author would like to thank the participants of the conference 'Solidarity in Hard Times: Solidarity and the European Social Model in times of economic crisis', (CEU San Pablo University, Madrid) as well as two
} 
anonymous referees for their valuable comments. All errors remain my own.

I See Article 2 TEU, Art. 122 TFEU and the 'solidarity clause' under Art. 222 TFEU.

II Borger has termed the solidarity that exists by reason of this interdependence as 'factual' solidarity, as opposed to the 'normative' solidarity which is distinguished from the 'factual' one as it aspires to serve a common good. See in Borger 2013: 10.

III See for instance Barnard 2005: 157-160; Giubboni 2007: 374; Somek 2007 and Ross 2010 who argue that solidarity is a legal concept in EU law.

IV In this sense, the principle of solidarity is unable to fulfil the direct effect conditions, that the obligations it entails must be precise, clear and unconditional and that they do not call for additional measures, either national or European.

$\mathrm{V}$ The concept of limited solidarity in the EU is not new but has been affirmed by the CJEU in Case C-184/99 Grzelczyk [2001] ECR I-6193, paragraph 44, and Case C-209/03 Bidar [2005] ECR I-2119, paragraph 56.

VI These questions draw heavily from the discussion on distributive justice. See, Rawls 1971, Nozick 1974 and Narveson 2003.

VII See Cases C-341/05 Laval un Partneri Ltd v Svenska Byggnadsarbetareforbundet [2008] and C-438/05 International Transport Workers' Federation v Viking Line ABP [2008]. For a discussion see Scharpf 2002 and Scharpf 2010.

VIII According to Stjernø, 'solidarity can most fruitfully be defined as the preparedness to share resources with others by personal contribution to those in struggle or in need and through taxation and redistribution organised by the state'. Similarly, for Habermas 'Such an effort would require Germany and several other countries to accept short and medium-term negative redistribution effects in its own longer-term self-interest — a classic example of solidarity [...] [Habermas 2013b].

IX In this sense, redistribution as used in this article encompasses the 'social dimension' of solidarity, for instance, the promotion of social welfare functions.

$\mathrm{x}$ For a discussion on the merits and demerits of progressive income taxation and its 'justice' see F.A. Hayek 'Taxation and Redistribution' in The Constitution of Liberty (Routledge Classics, 2006), 266-281.

XI See the famous critique of Nozick (1974) to Rawls (1971).

XII The idea of a Reciprocity Based Internationalism (RBI) was developed by A. Sangiovanni, as an idea best expressing EU solidarity at present. According to this concept, 'demands for social solidarity at all levels of governance can be understood as demands for a fair return in the mutual production of important collective goods' (Sangiovanni 2013).

XIII Note, however, the 'neoliberal' objection, according to which the EU cohesion policy's objective is to create an internal market insulated from political and governmental interferences. In this respect, cohesion policy has more an allocative rather than a distributive function, whereby it aims to stimulate growth and competitiveness in the market by increasing GDP per head rather than redistributing income to poorer regions. For this argument, see Marks 1996: 391.

XIV For the division between 'net payers' and 'net beneficiaries' see for instance, European Commission, 'Cohesion Policy 2007 - 2013: Commentaries and Official Texts' (2007) 24. According to the Commission's report of the past programming period, Poland figured as the leading recipient, followed by Italy, Spain, Hungary and the Czech Republic.

xv See Regulation 1303/2013, Article 19 'ex ante conditionalities'.

XVI OLAF reports that for $2011 € 691.4$ million was recovered as a result of OLAF's cases, out of which the highest recoveries were recorded in the structural funds sector ( $€ 524.7$ million), followed by customs (€113.7 million) and agriculture (€34 million).

XVII See for instance the opposition voices raised by the Netherlands and Denmark during the Agenda 2000 debate and by Sweden, the UK and Germany during the 2000 - 2005 period, in Bachtler et al. 2013: 130.

XVIII The Managing Authorities (MA) of the Member States are responsible for tasks ranging from the selection of operations and the management of the Funds to the auditing, payment, monitoring and drawing up of evaluation plans. (Art. 125 Reg. 1303/2013).

XIX On the pursuit of distributive and allocative goals through regulation see also Posner 1971: 22-23: '[...] only if we modify existing views by admitting that one of the functions of regulation is to perform distributive and allocative chores usually associated with the taxing or financial branch of government.' xx Case C-370/12 Pringle [2012] ECR I-0000.

xxi Case C-62/14 Gauweiler and Others v Deutscher Bundestag (OMT) of 16 June 2015, 
ECLI:EU:C:2015:400.

XXII I am referring here to the recent case law of the CJEU (Pringle, Gauweiler) as well as the Treaty amendment and the insertion of Art. 136 (3) TFEU.

XXIII Taking the example of Greece, the idea behind the first MoU and the Council Decision that incorporated it was to reinforce fiscal supervision and reduce the Greek deficit. Following this challenge both the $\mathrm{MoU}$ and the subsequent adjustment programmes laid out a very specific list of measures to be undertaken by Greece, including measures pertaining to direct taxation, limits to the maximum pensions and the abolition of the solidarity allowance. According to Article 2 Council Decision 2010/320/EU, 10 May 2010: 'Greece shall adopt the following measures before the end of June 2010: (a) a law introducing a progressive tax scale for all sources of income and a horizontally unified treatment of income generated by labour and capital assets; [...] (d) the abolition of most of the budgetary appropriation for the solidarity allowance (except a part for poverty relief) with the aim of saving EUR 400 million;(e) a reduction of the highest pensions with the aim of saving EUR 500 million for a full year (EUR 350 million for 2010); (f) a reduction of the Easter, summer and Christmas bonuses and allowances paid to civil servants with the aim of saving EUR 1500 million for a full year (EUR 1100 million in 2010); (g) the abolition of the Easter, summer and Christmas bonuses paid to pensioners, though protecting those receiving low pensions, with the aim of saving EUR 1900 million for a full year (EUR 1500 million in 2010) [...]'.

XXIV Regulation 1175/2011 amending Regulation 1466/97 on the strengthening of the surveillance of budgetary positions and the surveillance and coordination of economic policies [2011] OJ L306/12; Regulation 1177/2011 amending Regulation 1467/97 on speeding up and clarifying the implementation of the excessive deficit procedure [2011] OJ L306/33; Regulation 1173/2011 on the effective enforcement of budgetary surveillance in the euro area [2011] OJ L306/1; Directive 2011/85/EU on requirements for budgetary frameworks of the Member States [2011] OJ L306/41; Regulation 1176/2011 on the prevention and correction of macroeconomic imbalances [2011] OJ L306/25; Regulation 1174/2011 on enforcement measures to correct macroeconomic imbalances in the euro area [2011] OJ L306/8.

xxv The recent example of France is telling of the Commission's involvement in budgetary decision-making. After a long political clash between Paris and Brussels, the danger of France becoming the first Member State to be sanctioned for the first time for failing to comply with the EU set budget deficit standards, has for now been averted. On this see Dalton 2015.

XXVI The discussion on attributing the EU a fiscal capacity and on turning it into a full fiscal Union is not new; It was discussed during the negotiations of the 'failed' Constitutional Treaty and as a result of the Laeken Declaration but failed to pass the Council.

XXVII The report argued, inter alia that: 'The smooth functioning of the EMU requires not only the swift and vigorous implementation of the measures already agreed under the reinforced economic governance framework (notably the Stability and Growth Pact and the Treaty on Stability, Coordination and Governance), but also a qualitative move towards a fiscal union.'

XXVIII The creation of a new taxation power at the EU level, or a power to raise revenue by indebting itself on the markets (presently barred by Articles 310 and 311 TFEU) would require unanimity as provided under the ordinary revision procedure in Article 48 TEU.

xxix European Commission, Proposal for a Council Directive 'Implementing enhanced cooperation in the area of financial transaction tax', (14 February 2013) COM(2013) 71 final.

xxx The traditional own resources comprise custom duties from imports outside the EU, Gross National Income (GNI), VAT.

XXXI The enhanced cooperation mechanism does not attribute to the European Parliament the requisite role for the fulfilment of the principle 'no taxation without representation'. Instead, the Parliament's role could only be upgraded through the use of the 'passerelle clause' as provided in Art. 333 (2) TFEU. On the 'passerelle clause' see Amato 2007: 1272. On the use of the 'passerelle clause' in the EU's tax raising powers, see Fabbrini 2014: 173-174.

XXXII European Commission, A blueprint for a deep and genuine economic and monetary union - Launching a European Debate, (30 November 2012)COM(2012) 777 final/2, p. 33.

XXXIII To illustrate this, the left-leaning Syriza in Greece and Podemos in Spain have used the notion of solidarity as a sword to argue for further and deeper integration, while extreme right wing parties in France, Denmark and the UK have wielded solidarity as a shield against the very same process. These examples demonstrate the understanding of solidarity in its 'negative' sense, that is solidarity for one's self, directed to the satisfaction of one's own interest, for the Member State itself, as opposed to solidarity in its 'positive' 
sense which is undergone by the principles of reciprocity and altruism and is directed towards the 'common good'.

References

- Amato Giuliano, 2007, 'Future prospects for a European Constitution', in Amato et al. (eds) Genesis and Destiny of the European Constitution, Bruylant, Brussels.

- Bachtler John, Mendez Carlos and Wishlade Fiona (eds), 2013, EU Cohesion Policy and European Integration - The Dynamics of EU Budget and Regional Policy Reform, Ashgate, Farnham.

- Barnard Catherine, 2005, 'EU Citizenship and the Principle of Solidarity' in Spaventa Eleanor and Dougan Michael (eds), Social Welfare and EU Law, Hart Publishing, Oxford and Portland, 157 - 180.

- Barnard Catherine, 2006, 'Solidarity and New Governance in Social Policy' in de Burca Grainne and Scott Joanne (eds), Law and New Governance in the EU and the US, Hart Publishing, Oxford and Portland.

- Barry Brian, 1991, Liberty and Justice - Essays in Political Theory (Volume 2), Clarendon Press, Oxford.

- $\quad$ Borger Vestert, 2013, 'How the Debt Crisis Exposes the Development of Solidarity in the Euro Area', European Constitutional Law Review, IX(1): 7 - 36.

- Borgmann-Prebil Yuri and Ross Malcolm, 2010, 'Promoting European Solidarity: Between Rhetoric and Reality?' in Ross and Borgmann Prebil (eds) Promoting Solidarity in the European Union, Oxford University Press, Oxford.

- Closa Carlos, Kochenov Dand and Weiler J.H.H., 2014, 'Reinforcing Rule of Law Oversight in the European Union', EUI Working Paper, RSCAS 2014/25.

- Coppola Frances, 2015m 'Why Greek exit from the Euro would be a very bad idea', Forbes 17 February 2015 available at: http://www.forbes.com/sites/francescoppola/2015/02/17/why-greek-exitfrom-the-euro-would-be-a-very-bad-idea/.

- 'Corruption Perception Index' (CPI), 2014, available at: http://www.transparency.org/cpi2014/results.

- Dalton Matthew, 2015, 'EU Requests France Adopt Additional Budget-Deficit Cuts', The W all Street Journal, New York, 25 February 2015, available at: http://www.wsj.com/articles/france-must-make-budgetcuts-says-eu-1424882742 (last accessed 26 February 2015).

- de Witte Floris, 2012, 'Transnational Solidarity and the Mediation of Conflicts of Justice in Europe', European Law Journal, XVIII(5): 694-710.

- Draghi Mario (Speech), 2012, President of the ECB at the Global Investment Conference in London, 26 July 2012.

- Durkheim Emile, 1964, The Division of Labor in Society, The Free Press, Macmillan Publishing, New York.

- European Anti-Fraud Office (OLAF), 2011, Data on the use of the EU Funds available at: http://www.th-eu-nit.com/index.php?option=com content\&view=article\&id=1069:olaf-eus-european-antifraud-office-recovered-691million-in-2011-an-exceptional-amount\&catid=2:top-ten-archive\&Itemid=17.

- $\quad$ European Anti -Fraud Office (OLAF), 2014, Report, 'Fifteenth report of the European Anti-Fraud Office, 1 January to 31 December 2014'.

- $\quad$ European Commission, 2007, 'Cohesion Policy 2007 - 2013: Commentaries and Official Texts' (2007) 24.

- $\quad$ European Commission, 2012, A blueprint for a deep and genuine economic and monetary union Launching a European Debate, (30 November 2012) COM(2012) 777 final/2.

- $\quad$ European Commission, 2013a, Proposal for a Council Directive 'Implementing enhanced cooperation in the area of financial transaction tax', (14 February 2013) COM(2013) 71 final.

- European Commission, 2013b, 'Cohesion policy: Strategic report 2013 on programme implementation 2007-2013’ (18.4.2013) COM(2013) 210 final.

- $\quad$ European Commission, 2014a, European Commission's Country specific recommendations for 2014 available at: http://ec.europa.eu/europe2020/making-it-happen/country-specificrecommendations/index en.htm. 
- $\quad$ European Commission, 2014b, 'Alert Mechanism Report 2015', Report from the Commission to the European Parliament, the Council, the European Central Bank and the European Economic and Social Committee, 28 November 2014, COM(2014) 904 final.

- European Commission, 2014c, Sixth Report on Economic, Social and Territorial Cohesion 'Investment for Jobs and Growth - Promoting development and good governance in EU regions and cities' (July 2014).

- $\quad$ European Court of Auditors Press Release, 2013, '2013 Annual Report: EU must focus on getting better results from its spending', available at: http://www.eca.europa.eu/en/Pages/AR 2013.aspx.

- $\quad$ European Court of Auditors, 2014a, 'Annual Reports Concerning the Financial Year 2013'.

- European Court of Auditors Report, 2014b, 'EU-funded airport infrastructure: Poor value for money'.

- $\quad$ European Court of Auditors, 2014c, 'Making the best use of EU money: a landscape review of the risks to the financial management of the EU budget'.

- European Court of Auditors, 2015, Special Report 'Efforts to address problems with public procurement in EU cohesion expenditure should be intensified'.

- Fabbrini Federico, 2014, 'Taxing and spending in the Eurozone: legal and political challenges related to the adoption of the financial transaction tax' European Law Review, XXXIX(2): 155 - 174.

- Frankel Jeffrey A. and Rose Andrew K., 1996, 'The Endogeneity of the Optimum Currency Area Criteria', NBER Working Paper.

- Giubboni Stefano, 2007, 'Free Movement of Persons and European Solidarity', European Law Journal, XIII(3): $360-379$.

- Giubboni Stefano, 2010, 'A Certain Degree of Solidarity? Free Movement of Persons and Access to Social Protection in the Case Law of the European Court of Justice', in Ross Malcolm and Borgmann-Prebil Yuri (eds), Promoting Solidarity in the European Union, Oxford University Press, Oxford, 166 - 198.

- $\quad$ Habermas Jürgen,2011, 'Democracy is at stake', Le Monde 27 October 2011.

- Habermas Jürgen, 2013b, 'Democracy, Solidarity and the European Crisis', Social Europe (May 2013).

- Hallerberg Mark, 2014, 'Why is there Fiscal Capacity but Little Regulation in the US, but Regulation and Little Fiscal Capacity in Europe? The Global Financial Crisis as a Test Case' in Genschel Philipp and Jachtenfuchs Markus (eds) Beyond the Regulatory Polity?: The European Integration of Core State Powers, Oxford University Press Oxford, 87-104.

- Hannequart Achille, 1992, 'Economic and Social Cohesion and the Structural Funds: an introduction', in Hannequart (ed) Economic and Social Cohesion in Europe: A new objective for integration, Routledge, London and New York.

- Harvey Jean, 2007, 'Moral Solidarity and Empathetic Understanding: The Moral Value and Scope of the Relationship', Joumal of Social Philosophy, XXXVIII: 22 -37.

- Hayek Friedrich August, 'Taxation and Redistribution', in The Constitution of Liberty, Routledge Classics, Abingdon, 266-281.

- Hilpold Peter, 2014, 'Understanding Solidarity within EU law: An Analysis of the 'islands of solidarity' with particular regard to Monetary Union', available at: http://papers.ssrn.com/sol3/papers.cfm?abstract id=2599725\&download=yes.

- Jacoby Wade, 2014, 'The EU Factor in Fat Times and in Lean: Did the EU Amplify the Boom and Soften the Bust?', Journal of Common Market Studies, LII(1): 52 - 70.

- Juncker Jean-Claude, Tusk Donald, Dijsselbloem Jeroen, Draghi Mario and Schulz Martin, 2015, ‘Completing Europe's Economic and Monetary Union' Report (the 'Five Presidents' report).

- Maduro Miguel Poiares, 2012, 'A New Governance for the European Union and the Euro: Democracy and Justice’ RSCAS Policy Paper, 2012/11.

- Marks Gary, 1996, 'Exploring and Explaining Variation in EU Cohesion Policy', in Hooghe Liesbet (ed.) Cohesion Policy and European Integration: Building Multi-Level Governance, Clarendon Press, Oxford, 388 - 421.

- Mundell Robert A., 1961, 'A Theory of Optimum Currency Areas', The American Economic Review, LI: 657-665.

- Narveson Jan, 2003, 'We Don't Owe Them a Thing! A Tough Minded but Soft-Hearted View of Aid to the Faraway Needy', The Monist, LXXXVI(3): 419-33. 
- $\quad$ Neergaard Ulla, Nielsen Ruth and Roseberry Lynn M. (eds), 2010, The Role of Courts in Developing a European Social Model: Theoretical and Methodological Perspectives, DJØF Publishing, Copenhagen.

- Nicola Fernanda, 2015, 'Conceptions of Justice from Below: Distributive Justice as a Means to Address Local Conflicts in European Law and Policy' in Kochenov Dimitry, de Burca Grainne and Williams Andrew (eds), Europe's Justice Deficit?, Hart Publishing, Oxford and Portland, 349 - 365.

- $\quad$ Notre Europe Policy Paper (no. 137), 2015, 'Improving EMU: Our Recommendations for the Debate on the Five Presidents Report', 15 June 2015.

- $\quad$ Nozick Robert, 1974, Anarchy, State, and Utopia, Basic Books, New York.

- Plasschaert Sylvain, 2004, 'Towards an Own Tax Resource for the European Union? Why? How? And When?', European Taxation, XLIV(11): 470 - 479.

- Posner Richard, 1971, 'Taxation by Regulation', The Bell Journal of Economics and Management Science, II(1): $22-50$.

- $\quad$ Rawls John, 1971, A Theory of Justice, Harvard University, Press Cambridge, Massachusetts.

- Rawls John, 2001, Justice as Fairness: A Restatement, in Erin Kelly (ed), Harvard University Press, Cambridge, Massachusetts.

- $\quad$ Ross Malcolm, 2010, 'Solidarity - A New Constitutional Paradigm for the EU?', in M. Ross and Y. Borgmann Prebil (eds) Promoting Solidarity in the European Union, Oxford University Press, Oxford, 23 - 46.

- Sangiovanni Andrea, 2007, 'Global Justice, Reciprocity and the State', Philosophy \& Public Affairs, XXXV(1): 3-39.

- Sangiovanni Andrea, 2013, 'Solidarity in the European Union', Oxford Journal of Legal Studies, XXXIII(2): 213 - 241.

- Scharpf Fritz W., 2002, 'The European Social Model: Coping with the Challenges of Diversity', Journal of Common Market Studies, XL(4): 645-670.

- $\quad$ Scharpf Fritz W., 2010, 'The asymmetry of European integration, or why the EU cannot be a 'social market economy', Socio-Economic Review, VIII(2): 211-250.

- $\quad$ Somek Alexander, 2007, 'Solidarity decomposed: being and time in European citizenship', European Law Review, XXXII(6): 787 - 818.

- Steinar Stjernø, 2005, Solidarity in Europe: The History of an Idea, Cambridge University Press, Cambridge.

- Trichet Jean Claude, 2012, 'Reflections on Unconventional Monetary Policy Measures and on European Economic Governance: Towards an Economic and Fiscal Federation by exception', Mandeville Lecture 2012 - Erasmus University Rotterdam (6 June 2012).

- Vanistendael Frans, 2010, 'The Crisis: A Window of Necessity for EU Taxation', European Taxation, L(9): 394-401.

- Vanistendael Frans, 2011, 'Chapter 15: The European Union', in Bizioli Gianluigi and Sacchetto Claudio (eds), Tax Aspects of Fiscal Federalism, IBFD, Amsterdam.

- Van Rompuy Herman et al., 2012, Report 'Towards a Genuine Economic and Monetary Union', 5 December 2012.

- Viehoff Juri and Nicolaidis Kalypso, 2015, 'Social Justice in the European Union: The Puzzles of Solidarity, Reciprocity and Choice', in Kochenov Dimitry, de Burca Gráinne and Williams Andrew (eds), Europe's Justice Deficit?, Hart Publishing, Oxford and Portland, 277 - 293.

- Wishlade Fiona, 1996, 'EU Cohesion Policy: Facts, Figures and Issues', in Marks Gary and Hooghe Liesbet (eds), Cohesion Policy and European Integration: Building Multi-Level Governance, Clarendon Press, Oxford. 